\title{
A review on the present situation of wastewater treatment in textile industry with membrane bioreactor and moving bed biofilm reactor
}

Xuefei Yang

Institute of Textile Research and Industrial Cooperation of Terrassa (INTEXTER), Universitat Politècnica de Catalunya-BarcelonaTech (UPC), C/Colom 15, Terrassa 08222, Spain

937398260,xuefeiyang@hotmail.com

Martí Crespi

Institute of Textile Research and Industrial Cooperation of Terrassa (INTEXTER), Universitat Politècnica de Catalunya-BarcelonaTech (UPC), C/Colom 15, Terrassa 08222, Spain

937398247, crespi@etp.upc.edu

Victor López-Grimau

Institute of Textile Research and Industrial Cooperation of Terrassa (INTEXTER), Universitat Politècnica de Catalunya-BarcelonaTech (UPC), C/Colom 15, Terrassa 08222, Spain

Department of Project and Construction Engineering, Universitat Politècnica de Catalunya-Barcelona Tech (UPC), C/Colom 11, Terrassa 08222, Spain

937397316, victor.lopez-grimau@upc.edu 


\section{Abstract:}

Membrane bioreactor (MBR) is one of the advanced treatment technologies used in industrial wastewater treatment due to its various advantages over conventional biological processes. Recently, the application of MBR in treatment of textile wastewater has increased significantly with an effective removal of contaminants. Moving bed bioreactor (MBBR) has been efficiently used for the treatment of different municipal and industrial wastewater during the last decades and it is a relatively novel and effective technology applied for textile wastewater treatment. This review paper presents the situation of MBR and MBBR technology for textile wastewater purification under different conditions and collates results of previous studies during the past years about MBR and MBBR treatment technologies used in textile processes. Both of these two technologies have shown their efficiency but they still have problems in textile wastewater treatment. To this end, MBR-MBBR hybrid system could be an attractive solution for dyeing water purification because of the high efficiency and low consumption of energy and space.

Keywords: Membrane bioreactor; MBR; Moving bed bioreactor; MBBR; Textile wastewater 


\section{Introduction:}

The textile industry is one of the oldest and most complex sectors within the manufacturing industries with a series of inter-related processes. It consumes large quantities of water and produces large volumes of wastewater from different steps. Textile wastewater is often rich in color, containing a large range of organic chemicals, with high chemical oxygen demand (COD) and biochemical oxygen demand (BOD) concentration as well as hard-degradation materials. Therefore, understanding and developing effective treatment technologies for textile wastewater is environmentally important.

Textile wastewater treatment is a mixture of unit processes and those processes can be divided into three categories: physical-chemical treatment, biological treatment and combination of these two treatments. Among them, Membrane Bioreactors (MBR) are increasingly used for municipal and industrial wastewater treatment including textile wastewater treatment and Moving Bed Biofilm Reactors (MBBR) have been applied to treat textile wastewater in recent years.

MBRs are a combination of conventional biological wastewater treatment and membrane filtration. MBRs differ from conventional biological wastewater treatment in the separation of activated sludge and treated wastewater [1]. The influent is fed into the aerated bioreactor where organic components are oxidized by the activated sludge. The aqueous activated sludge solution then passes through a micro or ultrafiltration membrane filtration unit, separating the water from the sludge. The particles return to the bioreactor, while permeate is discharged or reused. Due to use of filtration unit in MBR, it is possible to retain all suspended solids and microbial flocks in the reactor. Consequently, a longer solid retention time (SRT) can be achieved in MBR systems. A previous review [2] reported that MBR systems for textile wastewater used in most previous studies removed more than $80 \%$ of COD and $70 \%$ of color. Thus, MBR is able to work more efficiently than traditional activated sludge process with high concentrations of biomass, MBBR is a wastewater treatment process using plastic carriers as a substrate for the formation of biofilms. It was firstly developed by Hallvard $\varnothing$ degaard at Norwegian University of Science and Technology in 1990s [3]. MBBR technology employs a large number of polyethylene biofilm carriers to support the growth of heterotrophic and autotrophic bacterias within its cells in a continuously mixed reactor. MBBR systems can be applied either for aerobic or anoxic processes. The main objective of MBBR is to decrease the volume of the biological reactor, or to be able to treat a larger organic load in the same reactor volume due to the increase of the concentration of biomass. In the study of Park et al. [4], COD and color removals in the pilot-scale MBBR process were $86 \%$ and $50 \%$, respectively. The largest amount of biomass is fixed in the added plastic support, and the concentration of biomass in suspension can be maintained at values similar to an activated sludge reactor. However, one of the main problems of MBBR is the poor decantation performance of biomass comparing to an activated sludge system. In many cases, this requires the addition of a certain amount of coagulant products if a wellclarified effluent is required.

Both of these two technologies have been highly developed in industrial wastewater treatment, but they have not been studied completely in textile wastewater treatment, especially MBBR, which is a relatively novel technology applied in this area. Therefore, the aim of this paper is to review the application of MBR and MBBR in textile wastewater treatment under different conditions.

\section{The state of art of MBR and MBBR technologies applied in textile wastewater treatment}

The increasingly restrictive environmental regulations are forcing textile industries to treat their effluents with more efficient systems [5]. The cost-effective biological decolorization is receiving much attention for the treatment of textile wastewater. As mentioned before, MBR system has been widely used in industrial wastewater treatment, including textile industry. MBBR system is a relatively new 
technology applied in this sector, although it has been developed as one of the most effective biological processes to treat industrial wastewater.

\subsection{The state of art of MBRs applied in textile wastewater treatment}

Two comparative studies of the performance of textile wastewater treatment by MBR and conventional biological system were carried out by Institute of Textile Research and Industrial Cooperation of Terrassa (INTEXTER). The results of these studies are demonstrated in the Table 1.

\begin{tabular}{|c|c|c|c|}
\hline Study & Type of treatment & $\begin{array}{l}C O D \\
\text { removal }\end{array}$ & Color removal rate \% \\
\hline \multirow[t]{2}{*}{1} & Conventional biological system & $70 \%$ & $<92$ (150-200 mg PAC*/L) \\
\hline & MBR & $81 \%$ & 92 (100 mg PAC*/L) \\
\hline \multirow[t]{2}{*}{2} & $\begin{array}{l}\text { Conventional biological system + } \\
\text { physical-chemical method }\end{array}$ & $86 \%$ & $<90(20-80$ ppm of resin) \\
\hline & MBR & $87 \%$ & $<90$ (80 ppm of resin) \\
\hline
\end{tabular}

Table 1. Results of two comparative studies of textile wastewater treatment by MBR and conventional biological system

The results obtained from the comparative studies above showed that MBR system performed more efficiently in COD removal and color removal than conventional biological system and also demonstrated that MBR resulted lower production of sludge and conductivity of the treated water, and also, the space required for the treatment plant was less as well as the operating costs.

\section{$\underline{\text { Application of aerobic MBRs }}$}

Schoeberl et al. [6] studied a submerged MBR under different operational conditions for treating dye wastewater. They observed that suction time was the most important factor to membrane fouling ability followed by aeration intensity and backflush time. The results of their study showed that COD and color removal of textile wastewater was $89-94 \%$ and $65-91 \%$, respectively. Similar observation was made by Brik et al. [7]. In their study, MBR reduced 74-90\% of COD and 46-98.5\% of color at $525 \mathrm{~nm}$. They noted that the main mechanism of color removal was adsorption of dye molecules onto biomass. Therefore, the sludge growth was important to maintain a maximum color removal efficiency. Chamam et al. [8] made a comparison of treating textile effluent by bio-sorption and membrane bioreactor. The iffluent in this study carried Cassulfon CMR which is a sulphuric textile dye mainly used to color "jeans" and the results confirmed the very high MBR potential to treat textile wasterwater with this type of dye. During operations, the organic load was increased from 0.33 to $1.33 \mathrm{~kg} \mathrm{~m}^{-3} / \mathrm{d}^{-1}$ and the permeate quality was always free of suspended solids or turbidity. In the same year, You et al. [9] compared the performance of MBR and sequencing batch reactor (SBR) for dyeing wastewater treatment in Taiwan. The removal efficiencies of the MBR system for color, COD, BOD, and SS were 54, 79, 99 and 100\%, respectively, all higher than the corresponding parameters of the SBR process. Futhermore, they observed that $79.6 \%$ of the total isolates belong to the genus Microbacterium and might be responsible for the textile dye degradation. The Paenibacillus azoreducens and Bacillus sp., are aslo identified as being the predominant type of textile dye degradation bacteria in the MBR sludge. A submerged hollow fiber aerobic MBR was studied by Huang et al. [10] showing that the system was capable to treat dyeing wastewater up to $400 \mathrm{~L} / \mathrm{d}$ and the removal ratio of COD reached $90 \%$ and $60-75 \%$ for color removal. Yigit et al. [11] investigated a pilot-scale aerobic MBR system for the treatment of textile wastewater 
from wet processes of a denim producing industry. Very high removal efficiencies were obtained for various parameters (COD, color, TSS, turbidity) and the treated wastewater had high potential for reuse in the textile industry. They observed that the working behavier of MBR system was not adversely affected by the changes in the influent characteristics, food/microorganism ratio, organic loading rate and specific substrate utilization rate.

Salazar and Martí [12] evaluated the kinetic coefficients using aerobic external MBR and AS treating textile wastewater. Both systems worked under the similar conditions. The kinetic constants for MBR's biomass founding in the pilot plant, were yield coefficient $(Y)=0.39 \mathrm{mg} \mathrm{MLSS} / \mathrm{mg}$ TOC.d, endogenous decay coefficient $k_{d}=0.01 \mathrm{~d}^{-1}$, maximum specific substrate utilization rate $(k)=0.47 \mathrm{~d}^{-1}$ and the halfvelocity constant $\left(\mathrm{K}_{\mathrm{s}}\right)=584 \mathrm{mg} \mathrm{TOC} / \mathrm{L}$. As for AS, biomass in pilot plant were $\mathrm{Y}=0.67 \mathrm{mg} \mathrm{MLSS} / \mathrm{mg}$ TOC.d, $\mathrm{k}_{d}=0.03 \mathrm{~d}^{-1}, \mathrm{k}=0.09 \mathrm{~d}^{-1}$ and $\mathrm{K}_{\mathrm{s}}=108 \mathrm{mg}$ TOC$/ \mathrm{L}$. These results can show that the MBR process is more attractive to treat textile wastewater than the CAS process, due to the less production of sludge, accepting high organic concentrations and higher substrate utilization rate. Salazar et al. [13] made another comparative study between aerobic MBR and AS treating in the same year. The results showed that the rate of reduction of COD was $89-92 \%$ with MBR while $54-70 \%$ with AS and the color removal rate was $72-73 \%$ with MBR (UF) and only $28 \%$ with AS. Konsowa et al. [14] carried out a study of the efficiency of aerobic submerged MBR (MF membrane) treating textile wastewater with direct fast red dye- $\mathrm{Cl} 81$. They observed that with the increase of HRT, the removal rate of COD and dye were improved. At $48 \mathrm{~h}$ of HRT, dye removal efficiency was achieved to 95\%. The research of Saha et al. [15] studied the first case of MBR applied in textile wastewater treatment in Bangladesh. MBR system performed better than the CAS system with a removal rate of COD $90 \%$ and BOD $80 \%$, respectively. Friha et al. [16] reported the performance of aerobic MBR in treating raw textile wastewater and the efficiency of the MBR in reducing cytotoxicity. High removal efficiencies were achieved in COD (98\%), color $(100 \%)$ and SS $(100 \%)$ and the cytotoxicity was significantly reduced by MBR when operating at HRT of 2 days. The results of aerobic MBRs applied in textile wastewater treatment are summarized in Table 2. 


\begin{tabular}{|c|c|c|c|c|c|c|c|c|}
\hline MBR type & Sample & Influent COD (mg/L) & COD removal (\%) & Color removal (\%) & $H R T(d)$ & $M L S S(g / L)$ & Flux & References \\
\hline Aerobic MBR & Dyehouse wastewater & $1606-2997$ & $89-94$ & $65-91$ & $2.9-5$ & 4 & $80 \mathrm{~m}^{3} / \mathrm{d}$ & {$[6]$} \\
\hline $\begin{array}{c}\text { Aerobic } \\
\text { External } M B R\end{array}$ & $\begin{array}{c}\text { Wastewater from a } \\
\text { polyester finishing factory }\end{array}$ & $1380-6033$ & $76-90$ & $46-98.5$ & $0.7-2.9$ & 5 & $\begin{array}{l}18-30 \\
L / m^{2} h\end{array}$ & [7] \\
\hline Aerobic MBR & Textile wastewater & - & 79 & 54 & - & - & - & [9] \\
\hline Aerobic MBR & Dyeing wastewater & $600-1200$ & $>90$ & $60-75$ & $6-22.5 \mathrm{~h}$ & $9-11$ & $2-8 \mathrm{~L} / \mathrm{m}^{2} \mathrm{~h}$ & [10] \\
\hline Aerobic MBR & $\begin{array}{l}\text { Denim producing textile } \\
\text { wastewater }\end{array}$ & $686-2278$ & 97 & $>97$ & $14 \mathrm{~h}$ & $13.9-17$ & $\begin{array}{c}380-1500 \\
L / d\end{array}$ & [11] \\
\hline Aerobic MBR & Texilte wastewater & 1500 & $89-92$ & $\begin{array}{c}70 \text { (MF membrane) } \\
72-73 \text { (UF } \\
\text { membrane) }\end{array}$ & 9 & 0.84 & $3.5 \mathrm{~L} / \mathrm{m}^{2} \mathrm{~h}$ & [13] \\
\hline Aerobic MBR & $\begin{array}{l}\text { Textile wastewater with } \\
\text { direct fast red dye-Cl } 81\end{array}$ & $2000-2500$ & $87.7-96.3$ & - & $4-48 h$ & $3-12$ & $\begin{array}{c}60-100 \\
L / m^{2} h\end{array}$ & [14] \\
\hline Aerobic MBR & Textile mill & $1800-2500$ & 90 & - & $177 \mathrm{~h}$ & 1.3 & $2-7 \mathrm{~L} / \mathrm{m}^{2} \mathrm{~h}$ & [15] \\
\hline Aerobic MBR & Textile wastewater & $1463-3089$ & $>90$ & $78-100$ & $1-3$ & 10 & $2-7 \mathrm{~L} / \mathrm{m}^{2} \mathrm{~h}$ & {$[16]$} \\
\hline
\end{tabular}

Table 2. Results of aerobic MBRs applied in textile wastewater treatment 
The review on previous studies of aerobic MBRs applied in textile wastewater treatment informed that the aerobic MBR technology is able to treat textile wastewaters with various characteristics. MBR system is resistant to changing loading rates and efficient COD removal occurs even at high loading rates. The results of these research projects showed that aerobic MBRs are effective in COD and color removal with a value range of $76-96.3 \%$ and $46-98.5 \%$, respectively. The value ranges obtained by this review are similar to those observed by Jegatheesan et al. [2].

\section{Application of anaerobic MBRs}

In recent years, anaerobic digestion has been widely applied for industrial wastewater treatment. The anaerobic MBR process improves the reliability of treatingindustrial wastewater by: a) Maintain the retention of biomass and maximum biogas production; b) Separate the solids retention time from the hydraulic retention time to improve biological performance; c) Save energy, as no aeration process is needed. Ivanovic and Leiknes [17] reported that anaerobic MBR had high total nitrogen and total phosphorus removal efficiency and generated smaller floc sizes and higher microbial activity in anoxic and anaerobic zones. Lin et al. [18] noted in their review study that the most popular application of AnMBR in industrial wastewater treatment appeared in food industrial wastewater treatment. The treatment of textile wastewater using AnMBR has been reported only once before the year 2013. In this study [19], a submerged anaerobic MBR (SAMBR) combined with powdered activated carbon (PAC) and another without PAC were applied in textile wastewater treatment. The SAMBR in the presence of PAC obtained the median removal efficiency of COD $(90 \%)$ and color $(94 \%)$ whereas for SAMBR in the absence of PAC the removal efficiency of COD and color was $79 \%$ and $86 \%$, respectively.

\section{Application of MBR combining other advanced treatment technologies}

\section{- Improving treatment efficiency}

The use of anaerobic MBRs for industrial wastewater treatment were very limited. More often, the combining of anaerobic unit and aerobic MBR were applied. Fan et al. [20] studied a treatment system for dye wastewater from a woolen mill. It was composed with an anaerobic tank and an aerobic MBR unit. The average removal of COD, BOD, color and turbidity was $82 \%, 96 \%, 71 \%, 99 \%$, respectively. They also made a comparative test of decoloration between $\mathrm{A} / \mathrm{O} \mathrm{MBR}$ and MBR without anaerobic unit and found that $A / O$ with an anaerobic biological unit had lower value of color in the effluent. Zheng et al. [21] reported the performance of a pilot-scale anoxic tank followed by a MBR on treating wastewater of Beijing Woolen Mill with the initial concentration range $179-358 \mathrm{mg} / \mathrm{L}$ of COD. The quality of treated water was excellent and met with the reuse water standard with the similar removal rate of the previous study. The study of Chung et al. [22] dedicated in getting a better insight of denitrification/nitrification MBR process and optimum operational conditions to treat tannery wastewater with high organic and nitrogen contents. Two experimental units, oxic MBR and anoxic/oxic MBR were operated. The results showed that anoxic/oxic MBR (COD removal rate 91.9\%) outperformed oxic MBR (COD removal rate $81.5 \%$ ) in removal efficiency of various parameters and in terms of nitrogen control. Zheng and Liu [23] carried out a study of a combined process of an anaerobic reactor and a MBR. The results showed that the removal rates of COD, BOD 5 , color and turbidity were $80.3 \%, 95 \%$, $59 \%$ and $99.3 \%$, respectively. In the study of You and Teng [24], an anaerobic SBR plus Aerobic MBR was tested for dyeing wastewater treatment containing an azo dye, Reactive Black 5. Nearly 92.3 and 5.2\% of COD removal and 74.6 and $9.1 \%$ of true color removal was achieved using the anaerobic SBR and the aerobic MBR respectively. The process showed excellent true color removal performance in the anaerobic part. Another study [25] evaluated the treatability of textile wastewaters in a bench-scale experimental system including an anaerobic biofilter, an anoxic reactor and an aerobic MBR followed by a NF membrane. The results showed a good COD (90-95\%) removal in the MBR system because of the 
presence of the anaerobic biofilter and an effective color removal (70\%) was obtained. Moreover, salt was also separated from effluent by the NF membrane, which allowed the reuse of effluent in the textile industry. Jager et al. [26] analyzed a pilot-scale dual-stage MBR (dsMBR) which was consisted of two phases: the side-stream UF-dsMBR followed by NF and RO. During the study the UF-dsMBR treatment system and RO polishing step showed average overall COD removals of 75 and $90.1 \%$, and color removals of 28.6 and $97.2 \%$, respectively. They had similar results in a study carried out in 2014 [27]. Tian et al. [28] carried out a study of the performance of hybrid anoxic/oxic MBR in simultaneous organic carbon and nitrogen removal from fiber wastewater. The results showed that the average removal efficiency of $\mathrm{COD}, \mathrm{NH}^{4+}-\mathrm{N}$ and $\mathrm{TN}$ in the hybrid $\mathrm{A} / \mathrm{O} \mathrm{MBR}$ could reach 56.5, 86.6 and $45.9 \%$ when HRT exceeded 37 hours. After supplementing alkalinity, the removal efficiency of $\mathrm{NH}^{4+}-\mathrm{N}$ and TN reached $86.9 \%$ and $60.5 \%$, respectively. These studies demonstrated that the anaerobic unit in MBR system could improve the biodegradability of the wastewater and made color of the effluent lower than that of effluent from the MBR system without anaerobic unit.

Brik et al. [29] tested three oxidation treatments to improve the efficiency of color removal of MBR: ozonation, chlorination and hydrogen peroxide oxidation. The result showed that ozonation was the most efficiency method because by using only $38 \mathrm{mg} / \mathrm{L}$ within 20 minutes, it was possible to achieve the reuse recommendation with a satisfactory color removal of 93\%. Yurtsever et al. [30] studied for the first time the performance of sulfate-reducing anaerobic and sulfide-oxidizing aerobic MBRs for treatment of synthetic textile wastewater. In this study, the COD/sulfate ratio ranged between 0.8 and 1.0 for compete COD and sulfate removal. The total COD removal rate was around $94 \%$ and almost complete decolorization was obtained in anaerobic MBR. Feng et al. [31] investigated the performance of $\mathrm{MBR}$ combined with Fenton oxidation for the treatment of dyeing wastewater. They used ferrous sulphate $\left(\mathrm{FeSO}_{4} \cdot 7 \mathrm{H}_{2} \mathrm{O}\right), \mathrm{H}_{2} \mathrm{O}_{2}(30 \%, \mathrm{~W} / \mathrm{W})$ and deithylene glycol (DEG) as reagents for Fenton oxidation process. The results showed that the removal of TOC and color was $88 \%$ and $90 \%$, respectively. Hybrid system oxidation-MBR also resulted excellent performance in color removal for textile wastewater treatment according to the studies above.

Qin et al. [32] studied enhanced MBR by internal micro-electrolysis (IE) for the degradation of anthraquinone dye wastewater. For comparison, a hybrid system MBR with iron ions fed (HMBR) and a control MBR ( CMBR ) were operated in parallel. The purpose of this study is to investigate the impact of iron released from IE process on sludge floc characteristics and membrane permeability. The results obtained showed that the iron had important effects on the structure and property of the flocs which is beneficial for TN removal.

Hai et al. [33] investigated the removal performance of two dyes (Poly S119 and Acid Orange II) in a membrane-coupled fungi reactor with/without PAC adsorption. They obtained excellent decoloration of both dyes with the PAC adsorption. Another research of Hai et al. [34] studied the key factors for fungal decolorization in MBR under non-sterile environment. The MBR obtained a 93\% removal efficiency of azo dye (Acid Orange II). Results demonstrated the adverse effect of bacterial contamination on fungal activity. Acikgoz et al. [35] investigated the reactive dye removal ability of mixed filamentous fungal strains ( $R$. arrhizus and $A$. versicolor) with submerged MBR in non-sterile conditions. They had the conclusion of using mixed fungal strains in the MBR system is efficient for removing reactive dyes with the removal efficiency of color and COD were $90.71 \%$ and $90 \%$, respectively.

\section{- Membrane fouling control}

Sun et al. [36] studied the performance of an anaerobic-anoxic-aerobic $\left(A^{2} O\right) M B R$ at removing organic compounds and nitrogen for treatment of textile wastewater. After the gas chromatograph mass spectrometer analysis, they found that only 20 kinds of refractory organic compounds were detected in 
the effluent while there were 121 types of organic compounds in the wastewater. They found that bacterial foulants were significant contributors to membrane fouling by scanning electron microscopy analysis. The bridge between foulants and inorganic compounds enhanced the formation of gel layer and caused membrane fouling. The chemical cleaning method using a combination of acids and oxidizing agents is recommended in their paper for fouled membrane caused by organic foulants and inorganic compounds. In the study of Yurtsever et al. [30], they found that the membrane fouling and TMP increase is not only due to accumulation of organic foulants on the membrane surface, inorganics bridge organic molecules or precipitate on or into membrane. They observed that $\mathrm{S}, \mathrm{Al}, \mathrm{Ca}, \mathrm{Fe}$ and $\mathrm{Cu}$ were distributed and contributed to inorganic fouling together.

In the study of MBR with internal micro-electrolysis (IE) treating dye wastewater by Qin et al. [32], they found that the enhancement of settleability and compactability of flocs helped to control the membrane fouling and bound EPS effectively enhanced the bioflocculation of small particles in order to alleviate membrane biofouling.

In a study carried out by Yan et al. [37] a pilot-scale hybrid coagulation-MBR was investigated for textile wastewater treatment. Poly-aluminum chloride (PACL) was used in the process. The hybrid system achieved much higher organic matter removal than that of MBR which alleviated membrane fouling. They also proved this conclusion in another study of 2012 that coagulation with PACL in MBR decreased the pore resistance and the total fouling resistance effectively [38]. Teli et al. [39] reported MBR fouling control and permeated quality enhanced by PACL. The pilot plant operated in two steps: 7.5 months without flux enhancer and 3 months with the addition of PACL. The addition of PACL showed a significant decrease of the filtration resistance due to cake layer formation and an increase of color and anionic surfactants removal rate. In the same year, another research [40] studied the fouling control of a submerged MBR treating dyeing wastewater by using Powder-Activated Carbon and Alum (PAC). The results demonstrated that the addition of PAC and Alum into the MBR system improved the control of membrane fouling. They found that the MBR-Alum operation obtained the best fouling control performance.

Hai et al. [41] reported the excellent fouling prevention capacity of a fungi (White-rot fungi C. versicolor) spacer-filled MBR. The results showed that the spacer modules maintained stable performance on cakelayer fouling for a month while usual modules exhibited fatal fouling within a day.

Deowan et al. [42] investigated a novel antifouling coating of UF commercial membrane applied for MBR process treating dyeing wastewater. They found that the commercial polymerisable bicontinuous microemulsion MBR module reduced the fouling problem significantly. The present MBR module showed $10 \%$ higher blue dye removal efficiency and a similar rate of COD removal efficiency of about $95 \%$ compared to commercial module.

Membrane fouling is a common problem in treating industrial wastewater. The membrane fouling is not only because of the accumulation of organic foulants on the membrane surface, the bridge between foulants and inorganic compounds enhanced the formation of gel layer that increase the TMP. Previous studies showed that coagulation coupled with MBR showed enhanced membrane fouling control ability because soluble matter, colloids and foulants tend to attach on the moving carriers (coagulant flocs) in a bulk liquid, which mitigated the membrane fouling. Micro-electrolysis also showed the ability to reduce the TMP. Another method is to use spacer modules MBR or novel antifouling material MBR to prevent membrane fouling. The results of MBR combining other advanced technologies applied in textile wastewater treatment are summarized in Table 3. 


\begin{tabular}{|c|c|c|c|c|c|c|c|c|}
\hline MBR type & Sample & Influent COD (mg/L) & COD removal (\%) & Color removal (\%) & $H R T(d)$ & $M L S S(g / L)$ & flux & References \\
\hline $\begin{array}{l}\text { Anaerobic + } \\
\text { aerobic MBR }\end{array}$ & Woolen mill & $54-473$ & 82 & 71 & $4.5-31.5 \mathrm{~h}$ & $1.24-3.33$ & $20 \mathrm{~L} / \mathrm{h}$ & [20] \\
\hline $\begin{array}{l}\text { Anaerobic + } \\
\text { aerobic MBR }\end{array}$ & Woolen mill & $179-358$ & 92.4 & 74 & $6-8 \mathrm{~h}$ & $0.2-10.4$ & $\begin{array}{c}5.4-9.4 \\
\mathrm{~m}^{3} / \mathrm{d}\end{array}$ & [21] \\
\hline $\begin{array}{l}\text { Anaerobic SBR } \\
\text { +aerobic MBR }\end{array}$ & Synthetic dyeing water & 300 & 97.5 & - & - & - & - & [23] \\
\hline $\begin{array}{l}\text { Anaerobic-anoxic- } \\
\text { aerobic MBR + NF }\end{array}$ & Textile wastewater & $400-1200$ & $90-95$ & $70-90$ & - & 7.7 & - & {$[25]$} \\
\hline UF-MBR+NF/RO & Textile wastewater & 5815 & $\begin{array}{l}75(\mathrm{UF}) \\
86(\mathrm{NF}) \\
90(\mathrm{RO})\end{array}$ & $\begin{array}{c}28.6(\mathrm{UF}) \\
98(\mathrm{NF}) \\
97(\mathrm{RO})\end{array}$ & - & 1.3 & $\begin{array}{c}9.5 \\
\mathrm{~L} / \mathrm{m}^{2} \mathrm{~h}\end{array}$ & {$[26]$} \\
\hline $\begin{array}{l}\text { Anaerobic-anoxic- } \\
\text { aerobic MBR }\end{array}$ & Textile wastewater & $657-944$ & 87 & - & $8.6-20 \mathrm{~h}$ & $3.5-5$ & $\begin{array}{c}8.52 \\
\mathrm{~L} / \mathrm{m}^{2} \mathrm{~h}\end{array}$ & {$[36]$} \\
\hline $\begin{array}{l}\text { Oxidation } \\
\text { treatments + MBR }\end{array}$ & Textile mill & $4000-6200$ & $>83$ & 90 & - & - & - & [29] \\
\hline $\begin{array}{l}\text { Sulfate-reducing } \\
\text { anaerobic/Sulfate- } \\
\text { oxidizing Aerobic } \\
\text { MBR }\end{array}$ & Synthetic dyeing water & $1000-2000$ & $\begin{array}{l}\text { AnMBR } 94 \\
\text { AeMBR } 94\end{array}$ & $\begin{array}{l}99.6 \\
\sim 90\end{array}$ & $\begin{array}{l}\sim 1.9 \\
\sim 1.3\end{array}$ & $\begin{array}{l}10.8 \\
6.6\end{array}$ & $\begin{array}{c}\sim 4.5 \\
\mathrm{~L} / \mathrm{m}^{2} \mathrm{~h} \\
\sim 8.2 \\
\mathrm{~L} / \mathrm{m}^{2} \mathrm{~h}\end{array}$ & [30] \\
\hline $\begin{array}{l}\text { Fenton oxidation }+ \\
\text { MBR }\end{array}$ & Dyeing wastewater & $1100-1300$ & $72-83$ & 91.3 & $20 \mathrm{~h}$ & 4.5 & $\begin{array}{c}7.5 \\
\mathrm{~L} / \mathrm{m}^{2} \mathrm{~h}\end{array}$ & [31] \\
\hline IE-MBR & & 778 & 93.2 & 97.7 & $20 \mathrm{~h}$ & $4-5$ & $\begin{array}{c}4.5 \\
\mathrm{~L} / \mathrm{m}^{2} \mathrm{~h}\end{array}$ & \\
\hline $\begin{array}{l}\text { Coagulation + } \\
\text { MBR }\end{array}$ & $\begin{array}{l}93 \% \text { dyeing wastewater } \\
6 \% \text { fiber wastewater } \\
1 \% \text { domestic sewage }\end{array}$ & $383-534$ & 90.7 & 83.7 & - & $6.05-8.32$ & - & [37] \\
\hline $\begin{array}{l}\text { Coagulation + } \\
\text { MBR }\end{array}$ & $65 \%$ textile wastewater & 284 & 81 & 68 & $14.5 \mathrm{~h}$ & $4.4-7.6$ & $\begin{array}{c}10 \\
\mathrm{~L} / \mathrm{m}^{2} \mathrm{~h}\end{array}$ & [39] \\
\hline
\end{tabular}

Table 3. Results of MBR combining other advanced technologies applied in textile wastewater treatment 


\subsection{Status of MBBRs applied in textile wastewater treatment}

MBBR has been applied in many cases of industrial wastewater treatment, but it is a relatively novel technology for treating textile wastewater. Shin et al. [43] studied a combined process consisted of a MBBR and chemical coagulation for textile wastewater treatment. The MBBR system filled with polyurethane-activated carbon (PU-AC) had anaerobic-aerobic-aerobic in series followed by chemical coagulation with $\mathrm{FeCl}_{2}$. After the MBBR process, $85 \%$ of $\mathrm{COD}$ and $70 \%$ of color were removed. After the coagulation, $95 \%$ of COD and $97 \%$ of color were removed. Park et al. [4] reported an anaerobicanaerobic-aerobic MBBRs treating textile dyeing wastewater. Polyurethane-activated carbon (PU-AC) foam carriers were filled with $20 \%$ for biological treatment. After an eight-day operation, $86 \%$ of the total COD was removed. But they mentioned in the conclusion that a coagulation process is needed to achieve a more effective treatment. Gong [44] investigated a four-stage lab-scale treatment system (anaerobic-aerobic MBBR-ozonation-aerobic MBBR) in series for textile wastewater treatment. The optimum operating conditions were found to be $14 \mathrm{~h}$ HRT for both anaerobic for No. 1 aerobic MBBRs, 14 minutes ozonation time and $10 \mathrm{~h}$ HRT for No. 2 aerobic MBBR. The obtained results showed the removal efficiencies of COD, SS, ammonia and color were 94.3\%, 97.8\%, 85.3\% and 96.3\%, respectively. Castro et al. [45] also studied the combination of ozonation and MBBR for treating textile wastewater with Reactive Orange 16 azo dye. They had the similar results in COD and color removal rate of $90 \%$ and $97 \%$, respectively. However, they found that the dye content was mainly removed in the ozone odidation process and no color removal was obtained in MBBR reactor. Francis and Sosamony [46] studied the performance of MBBR on chemical pre-treated textile wastewater by Fenton oxidation. After Fenton oxidation process, COD is reduced and the biodegradability of textile wastewater is enhanced for MBBR treatment. Maximum COD removal was obtained at $67.06 \%$ filling ratio.

As shown in these previous studies, MBBR system often requires a coupled process, such as coagulation or oxidation, to achieve an effective performance for treating textile wastewater. The results of MBBR applied in textile wastewater treatment are summarized in Table 4.

\begin{tabular}{|c|c|c|c|c|c|c|c|}
\hline Carrier type & $\begin{array}{l}\text { Surface } \\
\text { area }\end{array}$ & Density & $\begin{array}{c}\text { Filling ratio } \\
(V / V)\end{array}$ & $H R T(h)$ & $\begin{array}{c}C O D \\
\text { removal }\end{array}$ & $\begin{array}{c}\text { Color } \\
\text { removal }\end{array}$ & Reference \\
\hline PU-AC & - & $136 \mathrm{~kg} / \mathrm{m}^{3}$ & $20 \%$ & 44 & $94.9 \%$ & $97.4 \%$ & [43] \\
\hline PU-AC & $59.7 \mathrm{~m}^{2} / \mathrm{g}$ & $1.064 \mathrm{~g} / \mathrm{m}^{3}$ & $20 \%$ & 44 & $86 \%$ & $50 \%$ & [4] \\
\hline Polyethylene & - & $0.98 \mathrm{~g} / \mathrm{cm}^{3}$ & $60 \%$ & 38 & $94.3 \%$ & $96.3 \%$ & {$[44]$} \\
\hline Polyethylene & $500 \mathrm{~m}^{2} / \mathrm{m}^{3}$ & - & $40 \%$ & 6 & $>90 \%$ & $97 \%$ & {$[45]$} \\
\hline $\begin{array}{l}\text { Poly Vinyl } \\
\text { CHloride }\end{array}$ & - & - & $67 \%$ & - & 87 & - & [46] \\
\hline
\end{tabular}

Table 4. Results of MBBR applied in textile wastewater treatment

\subsection{Status of MBR-MBBR applied in textile wastewater treatment}

The advantages and disadvantages of the MBBR and MBR systems are well known. Among the main advantages of the MBR systems, one of them is the ability to work at much higher biomass than activated sludge processes, which results in lower volume of biological reactors. However, we find that the reduction of reactor volume is limited because the biomass concentration in practice has a limit. Although membranes can withstand very high biomass concentration, usually biomass concentration does not exceed 8-10 g / $\mathrm{L}$ in practical cases to avoid too much influence on oxygen transfer coefficient 
" $\alpha$ ". One of the main advantages of MBBR system is to reduce the volume of the biological reactor, or to treat a larger organic load in the same reactor volume. When the majority of biomass is fixed on added carriers, the biomass concentration in suspension can be maintained at values similar to those of activated sludge reactors. However, this often requires the addition of a certain amount of coagulants if we want a well clarified effluent. Both of these two technologies have been quite developed in industrial wastewater treatment, but there are still problems of applying them in textile wastewater treatment and MBR-MBBR hybrid system could be an attractive solution for dyeing water purification.

Pervissian et al. [47] did an assessment of the performance of MBBR-MF system for treatment of industrial wastewater. The total COD removed was $97 \%$ and the fouling of the membrane was reduced with the MBBR. To our best knowledge, there was only one study [48] about MBBR-membrane filtration applied in textile wastewater treatment, in which a combined anaerobic-aerobic MBBR-MF was investigated for the treatment of azo dye reactive brilliant red X-3B. The biofilm carriers were made of polyethylene with a filling ratio about $35 \%(\mathrm{~V} / \mathrm{V})$. The COD and color removal rate achieved at $85 \%$ and $90 \%$, respectively. The color reductions mainly occurred in anaerobic conditions.

\section{Conclusions:}

An overview of the previous studies on MBR and MBBR applied in textile wastewater treatment is given in this review work. The aim of this paper is to extract relevant information given in scientific papers in this particular area. MBR was found a well-developed technology in the treatment of textile wastewater, both aerobic and anaerobic processes were effective in COD and color removal of textile wastewater. Some of the combination processes of MBR and other advanced technologies were more specific in treating one or some contaminants, for example, hybrid aerobic-anaerobic MBR system and oxidationMBR process both resulted better color removal performance. MBBR process used in textile wastewater treatment showed that they are able to operate with high concentrations of biomass; however, MBBR needs a coupled process, such as coagulation or oxidation to improve the quality of effluent. In the process of literature searching, we found that only few studies have investigated the combination of $M B R$ and MBBR technologies. MBBR-MBR can work at high organic loading rates because MBBR remove the majority of biodegradable contaminants and the particulate components can be separated by MBR. Furthermore, MBBR-MBR system will reduce the space and energy consumption comparing with MBR. Therefore, development of the application of MBBR-MBR would be attractive to textile wastewater treatment as a reliable and effective method.

\section{References:}

[1] N. Çiçek, J. Franco, M. Suidan, V. Urbain, J. Manem, Characterization and Comparison of a Membrane Bioreactor and a Conventional Activated-Sludge System in the Treatment of Wastewater Containing High-Molecular-Weight Compounds, Water Environment Research. 71 (1999) 64-70.

[2] V. Jegatheesan, B. Pramanik, J. Chen, D. Navaratna, C. Chang, L. Shu, Treatment of textile wastewater with membrane bioreactor: A critical review, Bioresource Technology. 204 (2016) 202-212.

[3] H. $\varnothing$ degaard, B. Rusten, T. Westrum, A new moving bed biofilm reactor - applications and results, (1994).

[4] H. Park, S. Oh, R. Bade, W. Shin, Application of $A^{2} O$ moving-bed biofilm reactors for textile dyeing wastewater treatment, Korean Journal of Chemical Engineering. 27 (2010) 893-899.

[5] T. Robinson, G. McMullan, R. Marchant, P. Nigam, Remediation of dyes in textile effluent: a critical review on current treatment technologies with a proposed alternative, Bioresource Technology. 77 (2001) 247-255. 
[6] P. Schoeberl, M. Brik, M. Bertoni, R. Braun, W. Fuchs, Optimization of operational parameters for a submerged membrane bioreactor treating dyehouse wastewater, Separation And Purification Technology. 44 (2005) 61-68.

[7] M. Brik, P. Schoeberl, B. Chamam, R. Braun, W. Fuchs, Advanced treatment of textile wastewater towards reuse using a membrane bioreactor, Process Biochemistry. 41 (2006) 1751-1757.

[8] B. Chamam, M. Heran, R. Amar, A. Grasmick, Comparison of Textile Dye Treatment by Biosorption and Membrane Bioreactor, Environmental Technology. 28 (2007) 1325-1331.

[9] S. You, D. Tseng, S. Ou, W. Chang, Performance and microbial diversity of a membrane bioreactor treating real textile dyeing wastewater, Environmental Technology. 28 (2007) 935-941.

[10] R. Huang, J. Hoinkis, Q. Hu, F. Koch, Treatment of dyeing wastewater by hollow fiber membrane biological reactor, Desalination and Water Treatment. 11 (2009) 288-293. doi:10.5004/dwt.2009.863.

[11] N.O. Yigit, N. Uzal, H. Koseoglu, I. Harman, H. Yukseler, U. Yetis, G. Civelekoglu, M. Kitis, Treatment of a denim producing textile industry wastewater using pilot-scale membrane bioreactor, Desalination, 240 (2009) 143-150.

[12] L. Salazar, M. Crespi, Evaluation of kinetic coefficients using membrane bioreactor and active sludge process treating textile wastewater, Desalination and Water Treatment. 13 (2010) 471-478. doi:10.5004/dwt.2010.1044.

[13] L. Salazar, M. Crespi, R. Salazar, Comparative study between activated sludge versus membrane bioreactor for textile wastewater, Desalination and Water Treatment. 35 (2011) 101-109.

[14] A. Konsowa, M. Eloffy, Y. El-Taweel, Treatment of dyeing wastewater using submerged membrane bioreactor, Desalination and Water Treatment. 51 (2013) 1079-1090.

[15] P. Saha, M. Hossain, M. Mozumder, M. Uddin, M. Islam, J. Hoinkis, S. Deowan, E. Drioli, A. Figoli, MBR technology for textile wastewater treatment: First experience in Bangladesh, Membr. Water Treat., 5 (2014) 197-205.

[16] I. Friha, M. Bradai, D. Johnson, N. Hilal, S. Loukil, F. Ben Amor, F. Feki, J. Han, H. Isoda, S. Sayadi, Treatment of textile wastewater by submerged membrane bioreactor: In vitro bioassays for the assessment of stress response elicited by raw and reclaimed wastewater, J. Environ. Manage., 160 (2015) 184-192.

[17] I. Ivanovic, T. Leiknes, The biofilm membrane bioreactor (BF-MBR)-a review, Desalination and Water Treatment. 37 (2012) 288-295.

[18] H. Lin, W. Peng, M. Zhang, J. Chen, H. Hong, Y. Zhang, A review on anaerobic membrane bioreactors: Applications, membrane fouling and future perspectives, Desalination. 314 (2013) 169-188.

[19] B. Baêta, R. Ramos, D. Lima, S. Aquino, Use of submerged anaerobic membrane bioreactor (SAMBR) containing powdered activated carbon (PAC) for the treatment of textile effluents, Water Science \& Technology. 65 (2012) 1540-1547.

[20] Y. Fan, J. Wang, Z. Jiang, M. Chen, K. Xu, Z. Jia, Treatment of a dyeing wastewater from a woolen mill using an A/O membrane bio-reactor, Journal of Environmental Sciences. 12 (2000) 344-348.

[21] X. Zheng, Y. Fan, Y. Wei, A pilot scale anoxic/oxic membrane bioreactor (A/O MBR) for woolen mill dyeing wastewater treatment, Journal of Environmental Sciences. 15 (2003) 449-455. 
[22] Y. Chung, H. Choi, S. Lee, J. Cho, Treatment of Tannery Wastewater with High Nitrogen Content Using Anoxic/Oxic Membrane Bio-reactor (MBR), Journal of Environmental Science And Health, Part A. 39 (2004) 1881-1890.

[23] X. Zheng, J. Liu, Printing and dyeing wastewater treatment using combined process of anaerobic bioreactor and MBR, Huanjing Kexue/Environmental Science. 25 (2004) 102-105.

[24] S. You, J. Teng, Anaerobic decolorization bacteria for the treatment of azo dye in a sequential anaerobic and aerobic membrane bioreactor, Journal of the Taiwan Institute of Chemical Engineers. 40 (2009) 500-504.

[25] S. Grilli, D. Piscitelli, D. Mattioli, S. Casu, A. Spagni, Textile wastewater treatment in a bench-scale anaerobic-biofilm anoxic-aerobic membrane bioreactor combined with nanofiltration, Journal of Environmental Science and Health, Part A. 46 (2011) 1512-1518.

[26] D. De Jager, M. Sheldon, W. Edwards, Membrane bioreactor application within the treatment of high-strength textile effluent, Water Science \& Technology. 65 (2012) 907-914.

[27] D. De Jager, M. Sheldon, W. Edwards, Colour removal from textile wastewater using a pilot-scale dual-stage MBR and subsequent RO system, Separation and Purification Technology. 135 (2014) 135144.

[28] Z. Tian, W. Xin, Y. Song, F. Li, Simultaneous organic carbon and nitrogen removal from refractory petrochemical dry-spun acrylic fiber wastewater by hybrid A/O-MBR process, Environmental Earth Sciences. 73 (2015) 4903-4910.

[29] M. Brik, B. Chamam, P. Schöberl, R. Braun, W. Fuchs, Effect of ozone, chlorine and hydrogen peroxide on the elimination of colour in treated textile wastewater by MBR, Water Science and Technology. 49 (2004) 299-303.

[30] A. Yurtsever, Ö. Çınar, E. Sahinkaya, Treatment of textile wastewater using sequential sulfatereducing anaerobic and sulfide-oxidizing aerobic membrane bioreactors, Journal of Membrane Science. 511 (2016) 228-237.

[31] F. Feng, Z. Xu, X. Li, W. You, Y. Zhen, Advanced treatment of dyeing wastewater towards reuse by the combined Fenton oxidation and membrane bioreactor process, Journal of Environmental Sciences. 22 (2010) 1657-1665.

[32] L. Qin, G. Zhang, Q. Meng, L. Xu, B. Lv, Enhanced MBR by internal micro-electrolysis for degradation of anthraquinone dye wastewater, Chemical Engineering Journal. 210 (2012) 575-584.

[33] F. Hai, K. Yamamoto, F. Nakajima, K. Fukushi, Removal of structurally different dyes in submerged membrane fungi reactor-Biosorption/PAC-adsorption, membrane retention and biodegradation, Journal of Membrane Science. 325 (2008) 395-403.

[34] F. Hai, K. Yamamoto, F. Nakajima, K. Fukushi, Factors governing performance of continuous fungal reactor during non-sterile operation - The case of a membrane bioreactor treating textile wastewater, Chemosphere. 74 (2009) 810-817.

[35] C. Acikgoz, Ü. Gül, K. Özan, A. Borazan, Degradation of Reactive Blue by the mixed culture ofAspergillus versicolorandRhizopus arrhizusin membrane bioreactor (MBR) system, Desalination and Water Treatment. 57 (2014) 3750-3756. 
[36] F. Sun, B. Sun, J. Hu, Y. He, W. Wu, Organics and nitrogen removal from textile auxiliaries wastewater with A2O-MBR in a pilot-scale, Journal of Hazardous Materials. 286 (2015) 416-424.

[37] Z. Yan, S. Wang, X. Kang, Y. Ma, Pilot-Scale Hybrid Coagulation/Membrane Bioreactor (HCMBR) for Textile Dyeing Wastewater Advanced Treatment, 2009 3Rd International Conference On Bioinformatics And Biomedical Engineering. (2009).

[38] Z. Yan, S. Wang, X. Kang, Y. Ma, Enhanced removal of organics and phosphorus in a hybrid coagulation/membrane bioreactor (HCMBR) for real textile dyeing wastewater treatment, Desalination and Water Treatment. 47 (2012) 249-257.

[39] A. Teli, M. Antonelli, L. Bonomo, F. Malpei, MBR fouling control and permeate quality enhancement by polyaluminium chloride dosage: a case study, Water Science \& Technology. 66 (2012) 1289-1295.

[40] B. Thanh, N. Dan, N. Binh, Fouling mitigation in a submerged membrane bioreactor treating dyeing and textile wastewater, Desalination and Water Treatment. 47 (2012) 150-156.

[41] F. Hai, K. Yamamoto, K. Fukushi, F. Nakajima, Fouling resistant compact hollow-fiber module with spacer for submerged membrane bioreactor treating high strength industrial wastewater, Journal of Membrane Science. 317 (2008) 34-42.

[42] S. Deowan, F. Galiano, J. Hoinkis, D. Johnson, S. Altinkaya, B. Gabriele, N. Hilal, E. Drioli, A. Figoli, Novel low-fouling membrane bioreactor (MBR) for industrial wastewater treatment, J. Membr. Sci., 510 (2016) 524-532.

[43] D. Shin, W. Shin, Y. Kim, M. Ho Han, S. Choi, Application of a combined process of moving-bed biofilm reactor (MBBR) and chemical coagulation for dyeing wastewater treatment, Water Science \& Technology. 54 (2006) 181-189.

[44] X. Gong, Advanced treatment of textile dyeing wastewater through the combination of moving bed biofilm reactors and ozonation, Separation Science and Technology. 51 (2016) 1589-1597.

[45] F. Castro, J. Bassin, M. Dezotti, Treatment of a simulated textile wastewater containing the Reactive Orange 16 azo dye by a combination of ozonation and moving-bed biofilm reactor: evaluating the performance, toxicity, and oxidation by-products, Environmental Science and Pollution Research. 24 (2017) 6307-6316.

[46] A. Francis, K. Sosamony, Treatment of Pre-treated Textile Wastewater using Moving Bed Bio-film Reactor, Procedia Technology. 24 (2016) 248-255.

[47] A. Pervissian, W. Parker, R. Legge, Combined MBBR-MF for industrial wastewater treatment, Environmental Progress \& Sustainable Energy. 31 (2011) 288-295.

[48] B. Dong, H. Chen, Y. Yang, Q. He, X. Dai, Treatment of printing and dyeing wastewater using MBBR followed by membrane separation process, Desalination and Water Treatment. 52 (2014) 4562-4567. 